\title{
Evaluation of Teaching Practicum at the College of Educational Sciences from the Viewpoints of Student Teachers at Al-Hussein Bin Talal University (AHU)
}

\author{
Rima A. Abu Omar \\ Curriculum and Instruction Department \\ Al-Hussein Bin Talal University, Ma'an, Jordan \\ E-mail: rema.r.amjad@gmail.com \\ Sami F. Aljazi \\ Curriculum and Instruction Department \\ Al-Hussein Bin Talal University, Ma'an, Jordan
}

Hasan A. Al-Hasanat

Curriculum and Instruction Department

Al-Hussein Bin Talal University, Ma'an, Jordan

Received: March 19, 2018

doi:10.5296/jse.v8i2.12846
Accepted: April 16, 2018 Published: May 1, 2018

URL: https://doi.org/10.5296/jse.v8i2.12846

\begin{abstract}
The purpose of this study was to evaluate the teaching practicum at the college of educational science at Al-Hussein Bin Talal University (AHU) from student teachers' viewpoints. Descriptive survey research design was followed, in which 35 student teachers completed a questionnaire. The participants were student teachers who were enrolled in the practicum in the first semester of the 2016/2017 academic year. All the students were majoring in class teacher education. The questionnaire instrument consisted of 40 items that were grouped in four scales that include the roles of practicum supervisor, the roles of cooperating teacher, the roles of cooperating principal, and professional competencies. The results showed that the participants were satisfied with the practicum course. The results showed that the means of the participants' responses to the questionnaire's four scales, in descending order, were as the
\end{abstract}




\section{Macrothink}

following: professional competencies $(M=4.56, S D=0.43)$, the roles of practicum supervisor $(M=4.55, S D=.67)$, the roles of cooperating principal $(M=4.36, S D=.56)$, and the roles of cooperating teacher $(M=4.28, S D=.62)$. Based on the findings, it was recommended that the practicum supervisors should provide the practicum students and cooperating teachers and principals with practicum guidebook that shows the responsibilities of each party in the teaching practicum. In addition, cooperating teachers and principals should make sure that the students know about the cooperating school's system and regulations. Furthermore, the cooperating principal should be aware of the needs of practicum students through holding weekly meeting with them to identify the problems that might face these students during their practicum and to find the appropriate solutions to these problems.

Keywords: Evaluation, teaching practicum, student teachers, cooperating teachers 


\section{Introduction}

The development of educational institutions is strongly associated with the development of their educational programs. However, the quality of any educational program is monitored by the evaluation process of such program. The availability of correct and accurate information and data regarding an educational program would help assessing the quality of such program. This is particularly true in higher education instructions and their teacher training and education programs (Aljallad, 2006)

Teachers' education and training is one of the main focuses of the higher education institutions in different parts of the world. Teachers have integral roles and responsibilities in the educational process. Teachers' responsibilities include enhancing the educational process, making it positive and useful, and making it copes with the contemporary life and developments in societies (Ali, 2012). The world today is witnessing widespread scientific, cultural and technological developments. Such developments are characterized by being accurate and complex in their compositions. Therefore, developing countries needs to keep up with these developments in order to overcome the gap with developed countries, where this is particularly true in the in the field of education that usually has dynamic changes in educational and scientific dimensions (Aljamaai, 2010)

The educational policies and strategies, in most countries of the world, have focused on the process of teachers' education, preparation and qualification. The different educational systems across the world; that have different philosophies, objectives, social, economic and political systems, have paid great attention to enhance the process of preparing and qualifying their teachers and their educational programs. The effectiveness of any educational system is directly associated with enhancing the effectiveness of teachers preparation, qualification and training programs (Tom, 1999).

Therefore, the educators, at the national and international levels, have pointed to the importance of educating and training teachers, where that is evident in the results of educational research studies. For instance, the United State National Education Association (NEA) had pointed that the today's schools had multiple and varied challenges. Such challenges would require providing teachers with effective and high quality training and education, where teachers in 21 st century would face many challenges and obstacles in taking responsibilities of teaching new generations due to the of new characteristic of these generations (Aladgem, 2003) .

Educators agree that teacher quality is one of the most important factors that would influence students' achievement, performance, and behaviors. The professional development of teachers would resolve the problem of disparity in students' academic performance and achievements. Therefore, it is crucial of any educational system to pay attention to the teachers' training and education. However, to ensure high quality training and education for the teachers, the input and output of the training and education programs should be monitored and constantly evaluated. Teaching practicum is an important part of any teacher education and training program, where pre-service teacher education practicum allow teachers to 
connect their practical experiences and their theoretical knowledge and it act as indicator of the student teachers' educational abilities and capabilities (Smith \& Ingersoll, 2004).

Therefore, the evaluation process of an educational program has an important role in improving and developing teacher education and training programs. The evaluation process of an educational program would reveal the extent to which the program has made progress in achieving its objectives. In addition, evaluation process of teacher education program would identify the strength and weakness points of such program, where the program's administrators can use this information to support the strength points and address the weakness points and the areas for improvement.

\subsection{Research problem}

The idea of the current study originated from the need to evaluate the educational and instructional programs offered by the higher education institutions. Teaching practicum course, also known as field training at Al-Hussein Bin Talal University, is one of the most important components of the teacher education and training program. Teaching practicum give the student teachers the opportunity to apply knowledge, skills, educational experiences from theoretical courses they took at the university to the types of settings where they will work as teachers in the future. Teaching practicum course would positively influence student teachers' educational behavior, educational attitude, and affiliations to the teaching profession

It is noticeable that teachers have academic, educational, cultural and social weakness. Therefore, higher education educators need to reconsider teacher education programs, courses, and educational plans in the colleges of education. Teacher education programs should reconcile between traditional and modern educational trends in the preparation process of teachers.

Teaching practicum courses have been given increased attention by higher education educators. Therefore, educators and researchers have examined the different aspects of teaching practicum, the factors that would affect the quality of teaching practicum, and the way to improve the of teaching practicum. Practical training has great importance in the educational process and it is critical element in its success (Obaidat, 2007).

\subsection{The Research Questions}

The research questions in this study were:

- What are the levels of student teachers' satisfaction with teaching practicum at the college of educational science at AHU?

- Are there statistically significant differences at $(\alpha=05)$ in the levels of student teachers' satisfaction with teaching practicum at the college of educational science at AHU based on their gender, their Grade Point Average (GPA), and the location of selected cooperating school? 


\subsection{Importance of the Study}

- The current study evaluated the teaching practicum in terms of the roles of practicum supervisor, the roles of cooperating teacher, the roles of cooperating principal, and the acquired professional competencies.

- The study identified the current status of the teaching practicum at the college of educational sciences in AHU from the viewpoints of student teachers.

- The study findings would benefit the educators and administrators who are responsible for managing teaching practicum through providing them with useful information and recommendations that may contribute in the development and enhancement of the teaching practicum.

- The study would allow the student teachers to evaluate their teaching practicum since students have critical roles in the educational process.

- This study is the first of its kind to evaluate teaching practicum at Al-Hussein Bin Talal University.

- This study would encourage other researchers to conduct more studies that would evaluate teacher education programs in general and teaching practicum in particular.

\subsection{Purpose of the Study}

The purpose of this study was to evaluate the teaching practicum at the college of educational science at AHU from student teachers' viewpoints through answering the two research questions.

\subsection{Limitations of the Study}

The current study has some limitation as the following:

- The study sample was limited to the students enrolled in teaching practicum course in the first semester of the 2016/2017 academic year.

- The study took place in the first semester of the 2016/2017 academic year.

\subsection{Definition of Terms}

- Evaluation: The process of evaluation is the process of assigning a specific value for something (Alhindawi, 2003). As an operational definition, Alrimawi (2013) defined it as "the process by which a judgment is made on the extent to which the educational process achieves its objectives" (p.23)

- Teaching practicum: "The practical side of the student teachers preparation and qualification programs that provide student teachers with needed knowlhge and skills to perform teacher's roles and responsibilities, where the student teachers practice these roles and responsibilities in the classroom or outside the classroom under the supervision of the university practicum supervisor in collaboration with the school administrations and teachers" (Atiya \& Alhashmi, 2008; p.203). The researchers adopted the following 
operational definition of teaching practicum "it is the cooperating parties and participants in the implementation and success of the practical side of student teachers program represented by practicum supervisor, cooperating teacher, and cooperating principal, and the practicum procedures and activities."

- Student teacher: A student who enrolled in pre-service teacher education program at educational institution that responsible for preparing future teachers, granting them educational qualification, and providing them with needed expertise and teaching skills under the supervision and guidance of educational specialists (Brown, 2005). The researchers adopted the following operational definition of student teacher "a student in his/her fourth academic year majoring in class teacher at the College of educational sciences in AHU in the 2016/2017 academic year who was attending a school, chosen by the student himself/herself, at the directorate of education in Ma'an, to teach students in their first educational stage; that include first grade, second grade, and third grade; under the supervision of a faculty members from the college of educational sciences in AHU. The aim of this study was to identify his/her views of the teaching practicum".

- Cooperating teacher: The researchers adopted the following operational definition of the cooperating teacher "a teacher who works at a school in the ministry of education in Ma'an governorate in which the student teacher is conducting teaching practicum. Cooperating teacher is responsible for providing student teacher with guidance and educational advices and to cooperate with him/her in the educational situations in order to achieve the goals of the teaching practicum."

\section{Study Methodology and Procedure}

\subsection{Population and Sample of the Study}

The study population comprised all the student teachers enrolled in the teaching practicum course in the first semester of the 2016/2017 academic year in the class teacher major at college of education at AHU. The population size was 35 students. All the students were selected to represent the study sample because of the small population size. Participation in the study was voluntary; the participants provided their approval to participate in the study.

\subsection{Data Collection Method}

The data collection instrument was a questionnaire survey that was developed by the researchers based on related previous studies. The questionnaire instrument consisted of two parts. The first part included questions related to students' characteristics that include gender, GPA, and location of the cooperating school. The second part consisted from 40 items that were grouped in four scales that include the roles of practicum supervisor, the roles of cooperating teacher, the roles of cooperating principal, and professional competencies. The rating of students' responses was measured with a five-point Likert scale: 1 for strongly disagree, 2 for disagree, 3 for neutral, 4 for agree, and 5 for strongly agree. 


\subsection{Validity and Reliability of the Instrument}

To verify the validity of the questionnaire instrument, a group of faculty members at AHU were asked to review the questionnaire instrument in terms of the language, relevance of the items to the scales. Revisions were made to the questionnaire' items based on faculty members' comments and suggestions. The expert judges were used to validate the questionnaire instrument, where the item that was rated as relevant to the scale by $80 \%$ of the faculty members was kept in the questionnaire. Based on the opinions of the faculty members, no item was deleted, but revisions were made to the wordings of some items.

\subsubsection{Internal consistency}

In order to verify the internal consistency of the questionnaire scales, a pilot study was conducted in which 43 teachers, from outside the study, completed the questionnaire. The number of student teachers was limited, therefore teachers were asked to participate in the pilot study. Pearson's correlation coefficient was computed between the score of each item of a scale and the total score of the related scale. The results showed that there were statistically significant correlation between the score of each item of a scale and the total score of the related scale. The values of correlation coefficients were between 0.38 and 0.63 , where that reflect the validity of internal consistency of the items and scales in the questionnaire instrument.

\subsubsection{Reliability}

Reliability analysis was conducted on pilot study scores. Cronbach's alpha coefficients were computed for the participants' scores. In addition, split-half reliability coefficients and spearman brown formula were used check the reliability of the scales of the questionnaire instrument. Table 1 shows the values of Cronbach's alpha coefficients and split-half coefficients. The high values of the reliability coefficients indicated that the scales of the questionnaire instrument were reliable for the purpose of the study. 
Table 1. Summary of reliability analysis using Cronbach's alpha coefficients and split-half coefficients

\begin{tabular}{|l|l|l|}
\hline Category & $\begin{array}{l}\text { Cronbach's alpha } \\
\text { coefficients }\end{array}$ & Split-half coefficients \\
\hline The roles of practicum supervisor & 0.89 & 0.91 \\
\hline The roles of cooperating teacher & 0.44 & 0.55 \\
\hline The roles of cooperating principal & 0.92 & 0.95 \\
\hline Gained professional competencies & 0.86 & 0.85 \\
\hline Overall & 0.78 & 0.73 \\
\hline
\end{tabular}

\subsection{Data Analysis}

Statistical Package for the Social Sciences (SPSS) was used to analyze the collected data. The means and standard deviations of students' responses to each item and scale were computed. Multivariate analysis of variance (MANOVA) was conducted to determine relationships between students' levels of satisfaction of different aspects of the practicum course and their gender, GPA, and the location of selected cooperating school in terms of being fare or close from the university.

The rating of students' responses was measured with a five-point Likert scale: 1 for strongly disagree, 2 for disagree, 3 for neutral, 4 for agree, and 5 for strongly agree. The levels for students' approval to the questionnaire' items and scales were described as the following:

- Between 1 and 2.3 - Low

- $\quad$ Between 2.4 and 3.7-Medium

- $\quad$ Between 3.8 and 5 -High

\section{Theoretical Framework}

Recent developments in the educational systems emphasize on the roles and responsibilities of higher educational institutions in improving the quality of teacher education and training programs. Teacher education and training programs should be designed to make the teachers able to provide their students with of knowledge, information, and different educational skills. According to the current global trends, in order to make the teaching process enjoyable and useful for teachers and students, there are needs to pay attention to teacher education and training programs. The success of the educational process depends on the teachers who chose teaching as a career and who were willing to take responsibilities for teaching. Teachers 
should be willing to get through the needed education and training that would make them able take their responsibilities and carry out their duties (Alkhatib, 2008)

In general, the goal of education is to make a desired change in individual and community behaviors. The general goal of teacher education and training programs is to make desired changes in student teachers' knowledge, skills, abilities, attitudes, behaviors and personalities. Teacher education and training programs should make teachers able to do their educational and social tasks through achieving the educational goals. In addition, teacher education and training programs should be designed to translate these goals into concrete reality to ensure the development of the society and the achievement of society's ambitions (Aldwairi \& alqda, 2013)

Nowadays, teachers' roles are significantly different than they used to be. Nowadays, teachers' roles and responsibilities are not limited to impart the information to the students following specific curriculum and then to evaluate students' learning using different school tests. An increasing number of studies have shown that teachers' roles and responsibilities have considerably changed and there are needs to make the contemporary teachers have the required competencies and abilities to match the new roles and responsibilities (Nusseirat, 2006)

The practical training has been considered as an important part of the curricula for student teacher education programs in all countries of the world. Teaching practicum plays integral roles in teachers' preparation since it involves integrating and applying of previously studied theoretical knowledge from various academic, educational and psychological courses into real life educational settings (Tawalbeh, 2009). Teaching practicum would contribute in supporting the development of teachers' personalities, refining their teaching skills and showing their abilities and competencies (Alrimawi, 2013). Teaching practicum represent the first chance for student teachers to apply previously studied educational principles, concepts and theories to the types of settings where they will work as professional teachers. Therefore, teaching practicum is considered as the educational foundation for teachers and the starting point from which they would start to develop their personalities as teachers and to enhance their educational competencies (Ghanem \& Abu-shuaira, 2008).

Despite differences in teacher preparation trends, there is agreement among higher education educators that teacher education and training programs should include three areas of focus. First, the area of subject matter specialization that focuses on making the teachers familiar with his/her field of specialization. The second area is related to the educational and psychological competencies that focus on developing teacher's competencies in managing educational situations, dealing with students' cognitive and psychological needs and understanding and dealing with students' differences. The third area is related to the cultural competencies that focus on improving teacher's efficiency to meet the needs of the surrounding environment and society (Abu-Doga, \& Lolo, 2007).

The higher education educators highlight the importance of practical application section in the teacher education programs. Teaching practicum would give student teachers real-world experience to apply what they already learned in the classroom, where students can apply the 
previously studied educational and psychological theories, teaching methods, and educational principles and foundations in real life teaching situation (Alkhazraji, 2016). During the teaching practicum, the student teachers will learn about most important requirements of teaching profession, the characteristics of successful teaching practices, the popular teaching methods, the uses of educational means, the characteristics of school environment and systems, and the educational supervision process (Abu-Shuaira, 2013). Teaching practicum would enhance student teachers' teaching competencies and performance, satisfy their educational demands and tendencies, and help them know about their educational abilities and desires, which would not have been known without such training opportunities. Teaching practicum would enhance teachers' confidence and that would help these teachers to advance and progress in their teaching career (Obaidat, 2007).

The main purpose of teaching practicum is to develop student teachers' competencies that are necessary for their teaching profession in order to make them successful teachers. Teaching practicum allows student teachers to apply what they learn in the college of education to schools. During teaching practicum, student teachers can practice their teaching skills, build lesson plans, and prepare educational materials, apply teaching and evaluation methods. Teaching practicum allows student teachers' to gain school experience and master all the responsibilities and duties of the school teachers (Abu-alhaija, 2007) .

Teacher education programs should cope with advancements in information and communications technology and the applications of new technology in the educational systems. Therefore, teaching practicum should include educational activities that qualify future teachers to use computer and internet technologies. Teaching practicum's activities should improve student teachers' knowledge and skills in information systems and knowledge economy, teaching practicum should make student teachers familiar with the use modern educational strategies that integrate technologies in the educational process (Atiya \& Alhashmi, 2008)

\section{Literature Review}

Higher education educators and administrators have paid great attentions to teachers' educational and training programs since teachers have key roles and responsibilities in the educational process, they are considered as the leaders of the societies, and the societies rely on them to educate the new generations. Teachers are not only transmitters of knowledge but they are responsible for mental, moral, social and physical education of the new generations. In addition, they are responsible for achieving the educational goals and translate them into reality through modifying students' behaviors (Zayer et al., 2001).

Teacher education programs were designed to train and educate teachers in order to make them qualified teachers in particular subject or for particular grade. Teacher education programs aim to make the teachers able to practice the profession of teaching and making them able to provide their students with range of knowledge and skills, where one of the teachers' main responsibilities is to develop students' knowledge as well as other aspects of students' life (Menizel \& Alwan, 1997). 
Several research studies were conducted to examine students' performance in teaching practicum course from different perspectives of stakeholders. For instance, Alajez and Hamad (1999) conducted a study that examined students' performance in teaching practicum course from the perspectives of cooperating teachers and principals. The researchers used descriptive and analytic research methods, where they developed a questionnaire instrument that consisted of four scales: the personal and professional characteristics, teaching performance, classroom management skills, and professional behavior. The study sample consisted of 179 students from the Islamic University and Al-Azhar University; the sample represented $29 \%$ from the study population. The study found that the means of the participants' responses to the personal and professional characteristics scale was higher than the means of the participants' responses to other three scales. The means of the participants' responses to the teaching performance, classroom management skills, and professional behavior scales had close values. In addition, the results showed that there were no significant differences $(\alpha<0.05)$ in students' performance based on the university they belonged to, where the participants were from either the Islamic University or Al-Azhar University. The results showed that cooperating teachers and principals had close rating for students' performance from both universities. In addition, results showed that there were no significant differences $(\alpha<0.05)$ in overall students' performance based on their gender. However, there were significant differences $(\alpha<0.05)$ in mean scores to some items of questionnaire based on the university the students belonged to and based on their gender. The results showed that were significant differences $(\alpha<0.05)$ in students' performance based on their major, where that cooperating teachers and principals had higher rating for performance for students from the college education compared to the students form other colleges .

In another study that collect data from different stakeholders, Abu-raya (2007) conducted a study that aimed to evaluate practical teaching programs in the Jordanian University from the perspectives of cooperating principals, cooperating teachers, and practical teaching students. The study sample consisted of 315 participants that include: 37 principals, 135 teachers and 143 students. In order to collect data, three questionnaires were developed. The validity and reliability of the questionnaire instruments were verified. The results showed that participants believed that organizational and administrative components of the practical teaching programs were appropriate. However, the participants believed that there was room for improvements in practical teaching programs. The results showed that the participants were satisfied with the roles and responsibilities of practical teaching supervisors. The participants were satisfied with the practical teaching students' performance. Furthermore, the results showed that the student teachers have learned from the cooperating teachers and practical teaching supervisors. Based on the results, the researcher recommended that there was need to develop practical teaching programs to cope with the different developments in the national and international educational systems. In addition, there was need to conduct regular meetings between higher educational faculty members and cooperating principals and teachers, in order to provide these principals and teachers with recent developments related to their academic disciplines. 
In another study that was conducted in Jordan, Abu-shandi et al., (2009) conducted a study that aimed to assess the teaching practicum program at Zarqa Private University. The study examined student teachers' perspectives of the roles, responsibilities and performance of practicum supervisor, cooperating teachers, the cooperating principals. In addition, the study examined student teachers' perspectives of the cooperating school and the practicum program activities and procedures. Furthermore, the study examined the effect of students' gender, school location, students' GPA on their perspectives of the different components of practicum program. The study sample consisted of 96 students who were selected using purposive sampling method. A questionnaire instrument was developed to collect data. The questionnaire instrument consisted from 59 items. The validity and reliability of the questionnaire instrument were verified. The rating of students' evaluation of the components of the practicum education from the highest to the lowest was as follow: practicum supervisor, cooperating teachers, practicum program activities and procedures, the cooperating school, and finally cooperating principal. The results showed that there were no significant differences $(\alpha<0.05)$ in students' perspectives of the components of the practicum education based on their gender and GPA. However, there were significant differences $(\alpha<0.05)$ in students' perspectives of the roles, responsibilities and performance of the school principal based on the location of the school .

In another study that focused on female student teachers, Alghishawi and Alabadi (2010) evaluated the practicum program at Al-Zaytouna Private University from the perspectives of female student teachers. A questionnaire instrument, which consisted from 40 items, was developed to collect data. The questionnaire instrument collected data regarding students' perspectives of the roles and responsibilities of practicum supervisor, cooperating principles, and cooperating teachers. In addition, the questionnaire instrument collected data regarding students' perspectives of the practicum activities and procedures. The validity and reliability of the questionnaire instruments were verified. One hundred and forty seven student teachers completed the questionnaire in the 2009/2010 academic year. The results showed that the students believed that the practicum academic supervisor and cooperating teachers had high performance in fulfilling their roles and responsibilities. However, the students believed that cooperating principles had moderate performance in fulfilling their roles and responsibilities. In addition, the results showed some negative aspects in the practicum program and in the practicum activities and procedures. The study recommended that there was need to enhance and develop the technical and administrative aspects of practicum program. In addition, there was need to improve the communication and cooperation between the university and the cooperating schools.

In Kuwait, Alhumaidi (2015) conducted a study aimed at identifying the student teachers' perspectives of the effectiveness of the roles and responsibilities of practicum academic supervisors, cooperating teachers, and cooperating school principals. The participants were students in teaching practicum course at the faculty of basic education. In addition, the study examined the differences in students' perspectives based on their gender, discipline, GPA, and the location of cooperating school. The sample of the study consisted of 193 students who were enrolled in practicum course in the first semester of 2013/2014 academic year. A 
questionnaire instrument was used to collect data. The results of the study revealed that the students' believed that the levels of the effectiveness of the roles and responsibilities of practicum academic supervisors, cooperating teachers, and cooperating school principal ranged between moderate and high. The students believed that the levels of the effectiveness of the roles and responsibilities of practicum academic supervisors and cooperating teachers were high while the level of the effectiveness of the roles and responsibilities of cooperating school principal was moderate. In addition, the results showed that there were no significant differences in students' responses based on their gender, discipline (social or scientific), and location of the cooperating school. In addition, there were no significant differences in students' perspectives of effectiveness of the roles and responsibilities of cooperating school principal based on their GPA, However, there were significant differences in students' perspectives of effectiveness of the supervisory tasks of practicum academic supervisors and cooperating teachers based on their GPA.

In Oman, Alshukri (2015) conducted a study that aimed to evaluate English language teacher preparation program at the faculty of applied sciences in Al-Rustaq in Oman from students' viewpoints. The researcher developed a questionnaire instrument to collect data. The study sample consisted of 92 students who were in their third and fourth academic year. The ample consisted of 59 males and 33 females. The results showed the students expressed moderate level of satisfaction with the program, where the mean score of their responses to questionnaire instrument was 3.18. Participants were found to have responded most positively to courses and hours scale, followed by administrative and advising services scale, and then research and activities scale. The participants had responded least positively to instructor and teaching methods scale. In addition, there were no significant differences in students' responses to the questionnaire based on their gender, academic year, and GPA.

In Iraq, Alzaidi (2016) conducted a study that aimed to evaluate the practical education program for students of the faculty of basic education at university of Babylon from the point of views of the teacher students. In addition, the study examined the differences in students' perceptions of the program's components based on their gender. The study sample consisted from 66 students who were students in their fourth academic year in second semester in 2014/2015 academic year. The study sample was randomly selected. The researcher used the following statistical techniques: Chi-square tests, Pearson correlation coefficients, means, standard deviations, percentage weight, and independent samples t test. The results showed that the students' evaluation of some aspect of practicum program' was as follows: First, the faculty advisers and cooperating teachers were performing their tasks, where the students believed that the faculty advisers and cooperating teachers support was "available". Second, there were shortcomings in the providing support from cooperating principal and cooperating school, where the students believed that the cooperating principal and cooperating school support was "available to some extent". In addition, the students were not totally satisfied with procedures of the practical education program. The order of students' evaluation of the components of the practicum education from the highest to the lowest was as follow: faculty adviser, cooperating teachers, procedures of the practicum program, the cooperating school, 
cooperating principal. In addition, there were no significant differences in students' evaluation of practical education program based on their gender.

This study is different from previous because it examines four important aspects of teaching practicum that include the roles of practicum supervisor, the roles of cooperating teacher, the roles of cooperating principal, and the gained professional competencies. The previous studies did not discuss students' acquired professional competencies in teaching practicum course. Evaluating students' acquired professional competencies is important, where professional competencies enable the student to deal with daily school activities, actual classroom situations, and their students. Teaching practicum allows the student teachers to learn about the school system and how to deal with this system. To the best of researchers' knowledge, this study is the first of its kind to evaluate teaching practicum in the universities in the southern region of the Hashemite Kingdom of Jordan.

\section{Results and Discussion}

The first research question: What are the levels of student teachers' satisfaction with teaching practicum at the college of educational science at AHU?

In order to answer the first research question means and standard deviations were computed for students' responses to each scale of the questionnaire. (See Table2)

Table 2. Means and standard deviations of participants' responses to the four questionnaire scales: the roles of academic supervisor, the roles of cooperating school principle, the roles of cooperating teachers, and gained professional competencies

\begin{tabular}{|l|l|l|l|}
\hline Category & Mean & SD & Rank \\
\hline The roles of practicum supervisor & 4.55 & 0.67 & 2 \\
\hline The roles of cooperating teacher & 4.36 & 0.62 & 3 \\
\hline The roles of cooperating principal & 4.28 & 0.56 & 4 \\
\hline Gained professional competencies & 4.56 & 0.43 & 1 \\
\hline Overall & 4.44 & 0.51 & \\
\hline
\end{tabular}

Table 2 shows that the degree of participants' satisfaction with the different aspects of their teaching practicum was high $(M=4.44, S D=0.51)$. The results showed that the highest degree of participants' satisfaction was with the acquired professional competencies, followed by the roles of practicum supervisor, the roles of cooperating principal, and the roles of cooperating teacher, respectively. 


\section{Macrothink}

Journal of Studies in Education

ISSN 2162-6952

2018, Vol. 8, No. 2

The results indicated that the practicum supervisors, cooperating teachers, and cooperating principals were successful in providing student teachers with all the necessary training on the use of lesson preparation methods, educational aids, teaching methods, and evaluation methods. It is also evident that teaching practicum played active roles in guiding student teachers as well as revealing and enhancing their educational capabilities.

Furthermore, the means and standard deviations were computed for students' responses to each item in the fours scales of the questionnaire. Table 3 shows the means and standard deviations of participants' responses to the scale's items that measured the levels of their satisfaction with the roles and responsibilities of the practicum supervisor. 


\section{Macrothink}

Table 3. The means and standard deviations of participants' responses to the scale's items that measured the levels of their satisfaction with the roles and responsibilities of the practicum supervisor

\begin{tabular}{|c|c|c|c|}
\hline $\mathbf{N}$ & Item & Mean & SD \\
\hline 5 & $\begin{array}{l}\text { The practicum supervisor tracked and monitored my attendance at } \\
\text { school. }\end{array}$ & 4.77 & .68 \\
\hline 12 & $\begin{array}{l}\text { The practicum supervisor attended my second practical test (second } \\
\text { supervisory visit) on schedule. }\end{array}$ & 4.73 & .52 \\
\hline 1 & $\begin{array}{l}\text { The practicum supervisor constantly reviewed my lesson plan book } \\
\text { and recorded his/her observations. }\end{array}$ & 4.67 & .61 \\
\hline 8 & $\begin{array}{l}\text { The practicum supervisor met me after the completion of the class to } \\
\text { discuss my teaching performance. }\end{array}$ & 4.63 & .67 \\
\hline 3 & $\begin{array}{l}\text { The practicum supervisor instructed me to use more modern teaching } \\
\text { methods that were appropriate to the educational situation. }\end{array}$ & 4.60 & .56 \\
\hline 4 & $\begin{array}{l}\text { The practicum supervisor attended my second practical test (second } \\
\text { supervisory visit) on schedule. }\end{array}$ & 4.57 & .68 \\
\hline 2 & $\begin{array}{l}\text { The practicum supervisor focused on the educational outcomes and } \\
\text { their multifaceted types. }\end{array}$ & 4.53 & .51 \\
\hline 11 & $\begin{array}{l}\text { The practicum supervisor evaluated my teaching performance using } \\
\text { specific practicum visit form. }\end{array}$ & 4.50 & .63 \\
\hline 7 & $\begin{array}{l}\text { The practicum supervisor focused on developing my professional } \\
\text { teaching capabilities. }\end{array}$ & 4.50 & .63 \\
\hline 10 & $\begin{array}{l}\text { The practicum supervisor focused on developing my teaching } \\
\text { competencies that related to the instructional delivery and evaluation. }\end{array}$ & 4.47 & .82 \\
\hline 9 & The practicum supervisor accepted my opinions and views. & 4.37 & .93 \\
\hline 6 & $\begin{array}{l}\text { The practicum supervisor helped me to overcome the difficulties and } \\
\text { problems that faced me as student teacher. }\end{array}$ & 4.33 & .84 \\
\hline \multicolumn{2}{|c|}{ Overall } & 4.55 & .67 \\
\hline
\end{tabular}




\section{Ml Macrothink}

Table 3 shows that the degree of participants' satisfaction with the different roles and responsibilities of the practicum supervisor was high $(M=4.55, S D=0.67)$. Participants responded most positively to item 5 "The practicum supervisor tracked and monitored my attendance at school." $(M=4.77, S D=.68)$, and least positively to item 6 "The practicum supervisor helped me to overcome the difficulties and problems that faced me as student teacher." $(M=4.33, S D=.84)$.

The results showed that the student teachers believed that the practicum supervisors demonstrated high degree of fulfilling their assigned duties and responsibilities, especially with monitoring and tracking student teachers' school attendance. Regular school attendance is important for student teachers and it is one of their main responsibilities during the practicum. Regular school attendance would allow student teachers to learn about the different aspect of school system.

The participants responded most positively to items $512,1,8$, and 3 respectively. Item 12 stated that "The practicum supervisor attended my second practical test (second supervisory visit) on schedule.", item 1 stated that "The practicum supervisor constantly reviewed my lesson plan book and recorded his/her observations.", item 8 stated "The practicum supervisor met me after the completion of the class to discuss my teaching performance.", and item 3 stated that "The practicum supervisor instructed me to use more modern teaching methods that were appropriate to the educational situation.". The rank of the items indicated that the practicum supervisors focused on providing student teachers with practical teaching experience in order to make them able to meet the requirements of teaching profession in the future.

Participants responded least positively to item 6 "The practicum supervisor helped me to overcome the difficulties and problems that faced me as student teacher.", such response might be attributed to the work schedule of the practicum supervisors at the university, where their teaching load at the university might prevent them to instantly follow up the difficulties and problems that might face the student teachers during their practicum. The finding regarding student teachers' high degree of satisfaction with the roles and responsibilities of practicum supervisors aligned with the findings from similar research studies (Abu-shandi, et al, 2009; Alzaidi, 2016, Alghishawi \& Alabadi, 2013).

Table 4 shows the means and standard deviations of participants' responses to the levels of their satisfaction with the roles and responsibilities of the cooperating principal. 


\section{Mll Macrothink}

Table 4. The means and standard deviations of participants' responses to the scale's items that measured the levels of their satisfaction with the roles and responsibilities of the cooperating principal

\begin{tabular}{|c|c|c|c|}
\hline $\mathbf{N}$ & Item & Mean & $S D$ \\
\hline 1 & $\begin{array}{l}\text { The cooperating principal introduced me to the school } \\
\text { administrators and teachers at the beginning of the practicum. }\end{array}$ & 4.90 & 0.13 \\
\hline 3 & $\begin{array}{l}\text { The cooperating principal attended all the school activities such } \\
\text { as morning queue, rest times, and classes. }\end{array}$ & 4.50 & .82 \\
\hline 2 & $\begin{array}{l}\text { The cooperating principal explained to me the rules that govern } \\
\text { the school system before the start of the practicum. }\end{array}$ & 4.40 & .89 \\
\hline 8 & $\begin{array}{l}\text { The cooperating principal contributed in increasing my } \\
\text { motivation to participate in the educational process. }\end{array}$ & 4.27 & .94 \\
\hline 7 & $\begin{array}{l}\text { The cooperating principal made an effort to provide place that } \\
\text { can be used to conduct meeting between the practicum } \\
\text { supervisor and student teacher after the end of the class. }\end{array}$ & 4.27 & .94 \\
\hline 9 & $\begin{array}{l}\text { The cooperating principal was working to provide an appropriate } \\
\text { learning environment in the school. }\end{array}$ & 4.23 & .90 \\
\hline 10 & $\begin{array}{l}\text { The cooperating principal asked me to participate in the } \\
\text { activities that took place at the cooperating school. }\end{array}$ & 4.07 & .98 \\
\hline 5 & $\begin{array}{l}\text { The cooperating principal instructed the school teachers to help } \\
\text { the student teachers and to provide them with what they needed } \\
\text { to teach. }\end{array}$ & 4.07 & .83 \\
\hline 4 & $\begin{array}{l}\text { The cooperating principal cooperated with the practicum } \\
\text { supervisor regarding the proper implementation of my } \\
\text { practicum. }\end{array}$ & 4.07 & .98 \\
\hline 6 & $\begin{array}{l}\text { The cooperating principal conducted regular meeting with the } \\
\text { student teachers in order to make sure that they were } \\
\text { comfortable and to monitor their educational progress during the } \\
\text { practicum. }\end{array}$ & 3.83 & .83 \\
\hline \multicolumn{2}{|c|}{ Overall } & 4.36 & 0.56 \\
\hline
\end{tabular}


Table 4 shows that the degree of participants' satisfaction with the different roles and responsibilities of the cooperating principal was high $(M=4.36, S D=0$. 56). Participants responded most positively to item 5 "The cooperating principal me to the school administrators and teachers at the beginning of the practicum." $(M=4.9, S D=.13)$,

The results can be explained by the assumption that the school principals were fully aware of the administrative and educational characteristics of the practicum. They were able to instruct the student teachers to perform their responsibility during practicum time. The findings regarding students' high level of satisfaction with the roles and responsibilities cooperating principal differ from the findings of similar research studies (Abu-shandi, et al, 2009; Alzaidi, 2016; Alghishawi \&Alabadi, 2013; Alhumaidi, 2015) that showed that the student teachers were least satisfied with the roles and responsibilities of the cooperating principals.

Participants responded least positively to item 6 "The cooperating principal conducted regular meeting with the student teachers in order to make sure that they were comfortable and to monitor their educational progress during the practicum." $(M=3.83, S D=.83)$. This might be attributed to the busy schedule of the school principals, where they focus on the school management tasks and they fully relay on practicum supervisors and cooperating teachers in supervising practicum students.

Table 5 shows the means and standard deviations of participants' responses to the levels of their satisfaction with the roles and responsibilities of the cooperating teacher. 


\section{$\triangle$ Macrothink}

Table 5. The means and standard deviations of participants' responses to the scale's items that measured the levels of their satisfaction with the roles and responsibilities of the cooperating teacher

\begin{tabular}{|c|c|c|c|}
\hline $\mathrm{N}$ & Item & Mean & $S D$ \\
\hline 10 & $\begin{array}{l}\text { The cooperating teacher treated me with tact and respect in front } \\
\text { of class students. }\end{array}$ & 4.57 & .77 \\
\hline 9 & $\begin{array}{l}\text { The cooperating teacher accepted my interventions during the } \\
\text { class. }\end{array}$ & 4.43 & .68 \\
\hline 7 & $\begin{array}{l}\text { The cooperating teacher considered my professional needs and } \\
\text { demands. }\end{array}$ & 4.37 & .85 \\
\hline 2 & $\begin{array}{l}\text { The cooperating teacher showed me how to deal the elementary } \\
\text { students. }\end{array}$ & 4.37 & .72 \\
\hline 1 & $\begin{array}{l}\text { The cooperating teacher contributed in enhancing my teaching } \\
\text { capabilities and competencies. }\end{array}$ & 4.37 & .76 \\
\hline 3 & The cooperating teacher showed me how to plan for lessons. & 4.23 & .86 \\
\hline 6 & $\begin{array}{l}\text { The cooperating teacher facilitated my educational tasks during } \\
\text { the practicum in a cooperative way. }\end{array}$ & 4.23 & .86 \\
\hline 5 & $\begin{array}{l}\text { The cooperating teacher showed me how to analyze the } \\
\text { educational content. }\end{array}$ & 4.17 & 1.12 \\
\hline 8 & $\begin{array}{l}\text { The cooperating teacher provided me with after I delivered } \\
\text { lesson. }\end{array}$ & 4.10 & .96 \\
\hline 4 & $\begin{array}{l}\text { The cooperating teacher used modeling to demonstrate in front of } \\
\text { me new concepts, skills, or teaching strategies. }\end{array}$ & 4.00 & .74 \\
\hline \multicolumn{2}{|c|}{ Overall } & 4.28 & 0.62 \\
\hline
\end{tabular}

Table 5 shows that the degree of participants' satisfaction with the different roles and responsibilities of the cooperating teacher was high $(M=4.28, S D=0$. 62). Participants responded most positively to item 10 "The cooperating teacher treated me with tact and respect in front of class students." $(M=4.57, S D=.77)$. This can be explained by the characteristics of cooperating teachers, where the cooperating teachers were high quality teachers who had moral characters and they maintained positive relationships with the student 
teachers. Teachers' positive qualities are excepted since they are the educators of successive generations and they are role models for their students all the time.

Students' responses to the cooperating teacher scale indicated that cooperating teachers had great and positive effect on student teachers' personalities. In addition, the cooperating teachers had provided student teachers with scientific and educational knowledge as well and educational guidance and counseling in order to make them able to carry out their responsibilities as teachers in the future.

The finding regarding student teachers' high degree of satisfaction with the roles and responsibilities of cooperating teachers aligned with the findings from similar research studies (Abu -Shandi, et al, 2009; Alghishawi \& Alabadi, 2013; Alhumaidi, 2015; Alzaidi, 2016).

Participants responded least positively to item 4 "The cooperating teacher used modeling to demonstrate in front of me new concepts, skills, or teaching strategies." $(M=4.28, S D=.82)$. This can be explained by the suggestion that the cooperating teachers would follow the detailed semester academic plans that were developed to cover the educational content; the cooperating teachers might think that using instructional modeling would cause a delay to follow the academic plans during the semester.

Table 6 shows the means and standard deviations of participants' responses to the levels of their satisfaction with the acquired professional competencies during their practicum . 


\section{Macrothink}

Table 6. The means and standard deviations of participants' responses to the scale's items that measured the level of their satisfaction with the acquired professional competencies

\begin{tabular}{|c|c|c|c|}
\hline $\mathrm{N}$ & Item & Mean & $\mathrm{SD}$ \\
\hline 1 & $\begin{array}{l}\text { The teaching practicum made me gain experiences to solve } \\
\text { educational problem during my educational practice. }\end{array}$ & 4.70 & .54 \\
\hline 7 & $\begin{array}{l}\text { The teaching practicum helped me select the appropriate educational } \\
\text { activities for my students. }\end{array}$ & 4.67 & .61 \\
\hline 5 & $\begin{array}{l}\text { The teaching practicum helped me apply variety of teaching strategies } \\
\text { in the educational situations. }\end{array}$ & 4.67 & .55 \\
\hline 8 & $\begin{array}{l}\text { The teaching practicum helped me practice the morning queue } \\
\text { activities }\end{array}$ & 4.63 & .72 \\
\hline 9 & $\begin{array}{l}\text { The teaching practicum trained me on how to employ different types } \\
\text { of reinforcements at the right time for my students. }\end{array}$ & 4.60 & .62 \\
\hline 6 & $\begin{array}{l}\text { The teaching practicum taught me to consider individual differences } \\
\text { among students }\end{array}$ & 4.57 & .50 \\
\hline 4 & $\begin{array}{l}\text { The teaching practicum enhanced my competencies in classroom } \\
\text { management and class interactions. }\end{array}$ & 4.57 & .63 \\
\hline 2 & $\begin{array}{l}\text { The teaching practicum made me learn about the general outline of } \\
\text { class teacher's curriculum planning. }\end{array}$ & 4.50 & .63 \\
\hline 10 & $\begin{array}{l}\text { The teaching practicum made me able to identify and apply the } \\
\text { appropriate educational evaluation strategies. }\end{array}$ & 4.37 & .67 \\
\hline 3 & $\begin{array}{l}\text { The teaching practicum made me able to select the appropriate } \\
\text { teaching strategies for the different educational situations. }\end{array}$ & 4.33 & .71 \\
\hline \multicolumn{2}{|c|}{ Overall } & 4.56 & 0.43 \\
\hline
\end{tabular}

Table 6 shows that the degree of participants' satisfaction with the acquired professional competencies from the teaching practicum was high $(M=4.56, S D=0.43)$. Participants responded most positively to item 1 "The teaching practicum made me gain experiences to solve educational problem during my educational practice." $(M=4.70, S D=.54)$, and least positively to item 3 "The teaching practicum made able to select the appropriate teaching strategies for the different educational situations." $(M=4.33, S D=.62)$. 


\section{Al Macrothink}

The results suggest that the teaching practicum facilitated student teachers' acquisition of professional competencies that enabled them to learn about and deal with the daily school activities, classroom situations, and students' needs and problems. In addition, the acquired professional competencies contributed in directing student teachers in their educational practice. The teaching practicum allowed the student teachers to show and benefit from their educational capabilities in the right way. To the best of researchers' knowledge, there was no study that examined student teachers' levels of satisfaction with the acquired professional competencies from their teaching practicum.

Are there statistically significant differences at $(\alpha=05)$ in the levels of student teachers' satisfaction with teaching practicum at the college of educational science at AHU based on their gender, their Grade Point Average (GPA), and the location of selected cooperating school?

In order to answer the second research question, multivariate analysis of variance (MANOVA) was conducted to examine variations in participants ${ }^{6}$ satisfaction with teaching practicum at the college of educational science at AHU based on their gender, GPA, and the location of selected cooperating school. (Table 7)

Table 7. Results of (MANOVA) for student teachers' responses to the level of satisfaction of teaching practicum based on their gender, GPA, and location of selected cooperating school.

\begin{tabular}{|l|l|l|l|l|l|}
\hline Category & $\begin{array}{l}\text { Sum of } \\
\text { Squares }\end{array}$ & $\begin{array}{l}\text { Degree of } \\
\text { Freedom }\end{array}$ & $\begin{array}{l}\text { Mean } \\
\text { Square }\end{array}$ & F & Sig. \\
\hline Gender & 173.82 & 1 & 173.82 & 0.32 & 0.58 \\
\hline $\begin{array}{l}\text { Cumulative } \\
\text { average }\end{array}$ & 127.77 & 3 & 42.6 & 0.08 & 0.97 \\
\hline $\begin{array}{l}\text { Location of } \\
\text { the school }\end{array}$ & 302.67 & 2 & 151.3 & 0.76 & 0.76 \\
\hline Error & 12613.95 & 23 & 548.4 & & \\
\hline Total & 1058807 & 29 & & & \\
\hline
\end{tabular}

Table 7 showed that there were no significant differences $(\alpha=05)$ in the levels of student teachers' satisfaction with teaching practicum at the college of educational science at AHU based on their gender, GPA, and the location of selected cooperating school. In other words, there was consensus among students in their evaluation of the teaching practicum and their evaluation was not affected by their on their gender, GPA, and location of selected cooperating school. These findings aligned with the findings from similar research studies (Abu -Shandi, et al, 2009; Alshukri, 2015; Alhumaidi, 2015; Alzaidi, 2016). 


\section{Recommendations}

Based on the findings, the researchers suggested the following recommendations:

1. In order to improve students' satisfaction with the different aspects of practicum, the practicum supervisors should create a guidebook that shows the roles and responsibilities of each party in the teaching practicum.

2. In order to improve students' satisfaction with the practicum supervisors' performance, there is need to conduct training courses and seminars for practicum supervisors to develop their skills and knowledge.

3. The practicum supervisors should cooperate with the cooperating teachers to use modeling to demonstrate in front of student teacher new concepts, skills, or teaching strategies during their practicum.

4. The cooperating school principals and teachers should inform the student teachers about school system and instructions.

5. The cooperating principal need to learn about student teachers' needs through conducting weekly meetings with them in order to learn about and to solve their problems that they might face during the practicum.

6. There is a need to conduct more research studies that examine the potential problems that might hinder the achievement of the goals of teaching practicum.

7. There is a need to conduct more research studies that examine other aspects of teaching practicum that were not examined in the current study.

\section{References}

Abu -Shandi, Y., Abu -Shaireh, K., \& Ghbari, T. (2009). Evaluation of Practicum Teaching Program at Zarqa Private University and Suggestions for its Development. Al-Zarqa Journal for Research and Human Studies, 9(1).

Abu-alhaija, F. (2007). Practicum Teaching, Working Guidebook for Supervisors and Student Teachers. Dar Almnahej: Amman.

Abu-Doga, S., \& Lolo, F. (2007). Evaluation study for the teacher preparation program in the college of education of the Islamic University of Gaza. Journal of the Islamic University (Series of Humanities Studies) Volume XV, First Issue, 465 - 504 January 2007

Abu-raya, M. (2007). Evaluation of the Practicum Teaching Program at the University of Jordan from the Point of View of Principals, Cooperating Teachers and Student Teachers. Educational Sciences Studies, 34(1).

Abu-Shuaira, K. (2013). Practicim Training in Education between Reality and Expectation. Arab Community Library: Amman. 
Aladgem, R. (2003). Development of the Program for Preparing Teachers of Arabic language in Light of the Requirements of the Era. Mansoura University, Faculty of Education. Retrieved from http ://www.angelfire. Com/ma 4 / reda 1121/ S.htm

Alajez, F., \& Hamad, K. (1999). The Performance of the Students in Practicum Teaching Course in the Faculties of Education in the Palestinian Universities. Journal of the Islamic University, 7(1).

Aldwairi, M., \& Alqda, B. (2013). Guidebook of Practicum Teaching in Early Childhood. Amman: Dar Al-Fikr.

Alghishawi, R., \& Alabadi, M. (2013). Evaluation of Teaching Practicum Program in the Department of Educational Sciences at the Faculty of Arts at the University of Zaytuna Jordanian Private from the point of views of female student teachers. Journal of Educational Sciences Studies, 40(2).

Alhindawi, A. (2003). Investigation of the Book of Al-Ain For Khalil bin Ahmed Al-Farahidi. Beirut: House of scientific books.

Alhumaidi, H. (2015). The Effectiveness of the Roles and Supervisory Functions of Supervisors of Practicim Teaching in the Faculty of Basic Education in the State of Kuwait from the Point of Views of Student Teachers. The Educational Magazine. 30(118).

Ali, M. (2012). Contemporary Issues and Problems in Curricula and Teaching Methods. Amman: Dar Al-Masirah.

Aljallad, M. (2006). Evaluation of Teacher Preparation Program in Ajman Science and Technology Network. Journal of Educational and Psychological Sciences, Faculty of Education, University of Bahrain.

Aljmaai, A. (2010) .Teacher Training Competencies in Arabic Language for the Secondary Stage as a Model. Amman: Dar Yafa.

Alkhatib, A. (2008). Preparation of the Arab Teacher: Models and Strategies. Amman: The World of Modern Books.

Alkhazraji, A. (2016). Practicim Training, Reality and Expectation. Amman: Dar Almanhajia.

Alrimawi, A. (2013). Experimental Culture. Amman: The World of Modern Books.

Alshukri, H. (2015). Evaluation of the Preparation Program of English Teacher in the Faculty of Applied Sciences in Rastaq from the Perspective of Students of the Specialization. Research Presented to the International Conference Entitled: Preparing the teacher in the era of technology and knowledge, University of Nizwa.

Alzaidi, O. (2016). Evaluation of Practicum Teaching Program in the Faculty of Basic Education at Babylon University From the Perspective of Student Teachers. Journal of the Faculty of Basic Education for Educational Sciences and Humanities, 26. 
Atiya, M., \& Alhashmi, A. (2008). Teaching Practicum and its Applications in the Preparation of the Future Teacher. Amman: Curriculum House.

Brown, G., (2005). Microteaching and Practicum Training. Translated by Mohammad Reza Al - Baghdadi, Hayam Mohamed Reza Al - Baghdadi. Cairo: Dar Al-fikr Alarabi.

Ghanem, B., \& Abu-shaireh, K. (2008). Effective Teaching Practicum between Theory and Practice in the First grades of the Basic Stage. Amman: Arab Community Library.

Menizel, A., \& Alwan, A. (1997).The Impact of the Teaching Practicum Program on the New Social Sciences Curricula in the Practice of Educational Competencies and its Relation to Scientific Qualifications. Journal of Educational Sciences Studies, 24(1). University of Jordan.

Nusseirat, S. (2006). Methods of Teaching Arabic Language. Amman: Dar Al Shorouk.

Obaidat, S. (2007). Teacher Preparation and Development. Irbid: The World of Modern Books.

Royse, D., Thyer, B., Padgett, D., \& Logan, T. (2001). Program evaluation: an introduction. Belmont: Wadsworth/ Thomson Learning.

Smith, T., \& Ingersoll, R. (2004). What are the effects of induction and mentoring on beginning teacher turnover?. American Educational Research Journal, 41(3), 681-714. https://doi.org/10.3102/00028312041003681

Tawalbeh, H. (2009). Practical Applications in Practicum Teaching. Amman: Dar Al Masirah.

Tom, A. (1999). Restructuring Teacher Education Programs. Translated by Basheer Al-Issawi. Saudi Arabia: International Education Series, International Publishing House.

Zayer, S. (2001). The Problems Facing the Arabic Language Department and its Applications in the Faculty of Education / Ibn Rushd and their Attitudes towards the Teaching Profession. Al-Fath Journal, 15. 